\title{
TEACHER EDUCATOR'S PERCEPTIONS OF THE ELT METHODOLOGY COURSE CONTENT SUFFICIENCY: ACTION RESEARCH
}

ІГОР РОМАНИШИН, кандидат педагогічних наук, дочент, ДВНЗ "Прикарпатський національний університет імені Василя Стефаника", Україна

\section{ПОГЛЯДИ ВИКЛАДАЧА НА ДОСТАТНІСТЬ ЗМІСТУ КУРСУ МЕТОДИКИ НАВЧАННЯ АНГЛІЙСЬКОЇ МОВИ: ДОСЛІДЖЕННЯ ДІЯЛЬНОСТІ}

In the article, the author describes the procedures and results of the implementation of the pedagogical technology - the design and delivery of the three-hour session 'Introduction to Communicative Language Teaching and the History of Method' to the second-year pre-service English teachers at Vasyl Stefanyk Precarpathian National University, Ukraine aimed at enhancing students' understanding of basic ELT concepts and becoming prepared for the new methodology content to be covered in the spring term of the academic year of $2019 / 2020$. The study is based on the material of the experimental Core Curriculum "English Language Teaching Methodology. Bachelor's Level" implemented within the framework of the joint project of the British Council Ukraine and the Ministry of Science and Education of Ukraine "New Generation School Teacher". The author applied the research methods of comparison, generalisation, synthesis, induction and deduction, as well as carried out the classroom action research using such instruments for qualitative and quantitative data collection as teacher classroom observations, student surveys, and student self-assessment checklists. The analysis of the obtained results demonstrates that the suggested pedagogical technology (materials, activities, methods/

(C) I. Romanyshyn techniques, interaction of the subjects of educational process, etc.) helped the teacher educator and students to reach the objectives of the experimental study. The results of the study might be useful for the wider community of pre-service English language teacher educators in Ukraine and beyond.

Key words: content of the ELT Methodology Curriculum, ELT approaches/methods, training of new generation pre-service teachers, reflection, feedback.

Анотація. У статті автор описує процедури та результати впровадження педагогічної технології - розробки та викладання тригодинного практичного заняття "Вступ до комунікативного навчання мови та історії методу" для студентів другого курсу-майбутніх учителів англійської мови в Прикарпатському національному університеті імені Василя Стефаника, спрямованого на покращення розуміння студентами базових концептів методики навчання англійської мови та підготовку до опанування нового змісту курсу методики у весняному семестрі 2019/2020 навчального року. Дослідження грунтується на матеріалах експериментальної Типової програми "Методика навчання англійської мови. Освітній ступінь бакалавра" у рамках реалізації спільного проекту Британської Ради в Україні та Міністерства освіти і науки України "Шкільний вчитель нового покоління". Автор застосував дослідницькі методи порівняння, узагальнення, синтезу, індукції та дедукції, а також провів дослідження діяльності студентів в аудиторії, використовуючи такі інструменти для якісного та кількісного збору даних, як спостереження викладача, опитування студентів і контрольні списки самооцінки студентів. Аналіз отриманих результатів показав, що запропонована педагогічна технологія (навчальні матеріали, активності, методи/прийоми навчання, взаємодія суб'єктів освітнього процесу тощо) допомогла педагогу-викладачу та студентам досягти цілей експериментального дослідження. Результати дослідження можуть бути корисними для широкого кола осіб, які здійснюють підготовку майбутніх учителів англійської мови в Україні та за їі межами.

Ключові слова: зміст навчальної програми з методики навчання англійської мови, підходи/методи навчання англійської мови, підготовка майбутнього вчителя нового покоління, рефлексія, зворотній зв'язок.

General problem setting. According to the Educational Program of the specialty 014.02 Secondary Education (English Language and Literature), pre-service teachers of English study the course 'ELT Methodology'. In Semester 4, the discipline begins with the Unit 'Principles of Communicative Language Teaching' (Typova programa, 2020, $p$. 22). The purpose of the course unit is to create conditions for the successful training of students in accordance with the basic principles underlying the communicative teaching of a foreign 
language (hereinafter referred to as the CLT). As a result of studying the course unit, students are expected to be aware of the most significant changes in the history of foreign language learning/ teaching and their causes; basic approaches to and methods of FLT and related techniques $<\ldots>$ ways to create conditions and tools for the CLT in the classroom, and to be able to reflect on their own foreign language learning experience, as well as to analyze the tasks and lesson plans from the point of view of the CLT. The theoretical content is to be covered in nine faceto-face sessions (18 hours) and includes the following main topics: 'Methods and approaches in ELT'; 'The main principles and features of CLT'; 'Characteristics of a communicative task'; 'Implications of the communicative approach for classroom practice' (Typova programa, 2020, $p$. 40). The course unit includes a variety of organizational forms of training and obligatory control of the learned material at the final stage. A significant role is attached to the self-study of students, which is allocated 12 hours. According to the Core Curriculum, the self-study provides for the exploring of basic literature, in particular for preparation for practical classes and final (end-of-module/end-of-course) assessment (Typova programa, 2020, pp. 37-41). The map of sessions (thematic plan) worked out by the ELT Methodology course designers (who are members of the New Generation School Teacher project) suggests that the first three sessions of the course unit "Principles of Communicative Language Teaching" should give 'a brief outline and critique of such methods and approaches in ELT as Grammar Translation, Direct, AudioLingual, Silent Way, Total Physical Response, Suggestopedia, Intensive and Counselling' (Supplementary Materials Module 2, 2020, p. 3). We agree that it is important that the students familiarise themselves with the history of Method; however, we find the suggested content aspects insufficient to achieve some of the course unit outcomes mentioned above (see 1.1). The reasons behind are the following:

As it is the beginning of the new module of the ELT Methodology course, we believe that it is more important to let the pre-service teachers first become aware of the structure, content, and assessment specifications of the whole Module 2 (that includes three other course units and guided observation practicum), which might enable successful learning on the ELT Methodology course in Semester 4.

In the previous academic year of 2018/2019, according to the Core Curriculum, the students studied the basic methodology concepts individually, during self-study hours. As a result, on average 14 out of 32 students (that makes 43,8\%) demonstrated some difficulty, while 3 of them $(9,4 \%)$ inability, in differentiating between the terms 'EFL' and 'ESL', 'applied linguistics' and 'language teaching methodology', 'approach' and 'method', as well as 'technique' and 'design' - the notions they were expected to understand before dealing with the content areas of the first three sessions of the course unit (see above).

The mentioned above concepts are essential (fundamental) for understanding the content areas of the other units of the ELT methodology course and the successful completion of the pre-service foreign language teacher training program in general.

Thus, we consider that the above-mentioned reasons are convincing for revisiting the structure and expanding the content of the course unit "Principles of Communicative Language Teaching", with the subsequent implementation in the classroom (see below).

The study aims at designing and implementing the pedagogical technology aimed at improving the content and quality of the ELT methodology course unit "Principles of Communicative Language Teaching" delivered to the second-year studentteachers of English at Vasyl Stefanyk Precarpatian National Unversity within the framework of the joint project of the British Council Ukraine and the Ministry of Education and Science of Ukraine "New Generation School Teacher"; at sharing the results of the action research with the wider community of pre-service English language teacher educators in Ukraine and beyond.

Analysis of researches and publications. For the research purposes, we studied specialised scientific literature from printed and online resources (Bedevelska M.V. (2015); Binetska D.I. (2016); Bosa V.P. (2018); Krista D.M., Burrus J., Shaw E.
(2010); Lamb T.E. (2017); Leleko V.V. (2015); Lewis M., Hill J. (1992); Necheporenko M.A. (2019); Rodgers Th.S. (2001); Shastri P.D. (2010), etc.) and the materials of the New Generation School Teacher project (Core Curriculum. English Language Teaching Methodology. Bachelor's Level (2020), URL: https:// ngschoolteacher.wixsite.com/ngscht). We also applied the research methods of comparison, generalisation, synthesis, induction and deduction. In addition, we carried out the classroom action research that included the following stages: designing the session; delivering the session; collecting the qualitative data with such tools as teacher classroom observations and student surveys; collecting quantitative data by means of student self-assessment checklists, analysing the results of the experimental study, and making conclusions.

Outline of the main research material. Lead by the above-mentioned conclusions, we have introduced a three-hour session prior to those suggested by the thematic plan. Both parts of the introductory session were delivered to a group of 30 second-year pre-service teachers of English from the Foreign Languages Department at Vasyl Stefanyk Precarpathian National University, Ukraine on February 11 and February 18, 2020. The students were not selected for the experimental study, i.e. they were in their original academic setting. Besides, they were not aware of the changes introduced to the CLT course by the methodology teacher, which, in our opinion, will make the results of the study more reliable. Let us consider the design and delivery of the session 'Introduction to Communicative Language Teaching and the History of Method'. The procedures of the newly introduced session are described below.

Part 1 of the Introductory Session

Topic: Introduction to Module 2 of the ELT Methodology Course

Objectives: By the end of the session, students will be aware of the essentials of Module 2 of the ELT Methodology course: structure and content, outcomes, tasks for guided observation practice, assessment

Time: 80 minutes

Materials and equipment: Handouts 1, 2; ppt (see Appendices).

In Activity 1, the students first reflected on their experience of learning in Module 1 answering the questions: 
What units did you study last semester? Which of them did you like and why? What are the main psychological factors enhancing learning? What is the difference between SLA and SLL? How can we foster learner autonomy? Which of the units did you find challenging and why? Then, in groups of five, they shared their strengths and weak points of learning in the previous units of the Methodology course using 'Selfassessment checklists' (Supplementary Materials Module 1, 2020, pp. 35, 48, 62), which students had been asked to bring to the class. In the same groups, they also brainstormed ideas on how to eliminate the weaknesses, presenting them on a poster. In this way, the pre-service teachers shared ideas on how to fill the gaps in their knowledge.

In Activity 2, the students were demonstrated the session objectives, the title of Module 2 'Preparing to teach $1^{\prime}$ and the short version of the Module 2 Map on the screen to predict the content of the module and become acquainted with its structure. Then, the course teacher distributed Handout 1 and asked the students to express their expectations of the methodology course in the new module. Therefore, each student discussed his/her answers with a partner giving reasons for their answers.

In Activity 3, the students (in the same groups as above), using Handout 2 , first matched the outcomes with the units of Module 2. Then, they expressed and explained their choices. Afterwards, the students explored how the outcomes were represented in 'The Profile of a Newly-Qualified English Teacher' (Typova programa, 2020, pp. 20-21).

In Activity 4, the pre-service teachers engaged in reflecting on challenges they faced during their Guided Observation Practice (GOP) in the previous term. They came up with ideas how to overcome those problems. They also explored the tasks for GOP in Module 2 (School Experience Observation Tasks Module 2, 2020, pp. 3-4). The methodology teacher provided explanation where necessary and elicited from the students how the GOP was assessed and what requirements they were expected to meet to complete it successfully.

To round-up the first part of the session the course teacher invited the students to reflect on it focussing on the things they had explored. To followup the learning and prepare for the next class, the students were referred to the Core Curriculum to analyse the content of the CLT unit and prepare questions if any. They also were to read two extracts, one - from the article 'Language Teaching Methodology' by Theodore S. Rodgers (Rodgers, 2001) and the other - from the book Communicative Approach to the Teaching of English as a Second Language by Pratima Dave Shastri (Shastri, 2010) and to bring them to the next class.

Part 2 of the Introductory Session

Topic: Introduction to Communicative Language Teaching and the History of Method

Objectives: By the end of the session, students will be aware of the objectives and content of the CLT unit, demonstrate understanding of basic language teaching notions, and be able to identify main language teaching approaches and methods by their features

Time: 80 minutes

Materials and equipment: Handouts 1, 2, 3; ppt (see Appendices).

In Activity 1, the pre-service teachers first became aware of the objectives for the second part of the session. Afterwards, the methodology teacher elicited from them evidence of understanding the objectives and content of the CLT unit (which was based on the follow-up task from the first part of the session), encouraging asking-answering questions by the students themselves.

As Activity 2 was aimed at creating shared understanding of basic language learning and teaching principles, the students were asked to comment on the statements: 'Language teaching is teaching language', 'Language is what, how and why', 'Knowing the language is not enough', 'Students need to practise form as well as use', 'Natural language has a place in all courses', 'Hear, speak, read, write is a good sequence', 'Do not be afraid of the students' mother tongue', 'The student must use the correct language' (Lewis \& Hill, 1992). Using the 'Corners' technique they expressed agreement, disagreement or doubt concerning each statement, explaining the choice.

In Activity 3, the students triggered their thinking and showed understanding the difference between the notions of 'mother tongue', 'ESL' and 'EFL', as well as what 'applied linguistics' is and what it studies. The methodology teacher referred them to the text in Handout 1 (Language Teaching Approaches: Review, 2020) to check if they understood the notions right.

In Activity 4, the pre-service teachers worked in pairs answering the questions based on the texts they read at home (Rodgers, 2001; Shastri, 2010), using Handout 2: 'What is the main difference between approach and method?', 'How can design help to implement the method in a learning context?', 'What are preCommunicative Language Teaching (CLT) methods?', 'What approaches share the same basic principles as CLT?'.

To complete Activity 5 the students were made into groups of four to work on the distributed cut-ups (Handout 3). They matched the methods/ approaches with the definitions and after that underlined key features in each description. Finally, the course teacher elicited from the students which method/ approach(es) they seemed to have experienced as learners or students and asked them to comment on their choices.

In Stage 1 of Activity 6, the students worked in the same groups. The methodology teacher demonstrated the image of the 21 st-century skills (What are the 21 st-century skills every student needs? 2020) and asked them to explain which method or approach discussed above might meet the needs of present-day learners of foreign languages. The students were to come up, on a poster, with a list of ideas why it was important to learn about the history of Method. Then, a representative of each group commented on the group's ideas. In Stage 2 of the activity, the students watched the video (Diane LarsenFreeman on Techniques \& Principles in Language Teaching, 2020) to expand on their lists of ideas.

The suggested design and delivery of the session 'Introduction to Communicative Language Teaching and the History of Method' is, in our opinion, a pedagogical technology "the system of specific ways for reaching the objectives ..., which is characterized by relevant choice of methods, techniques, forms and means of teaching/learning, as well as teacher and students' actions that result in the essential growth of student motivation to the educational process (Leleko, 


\section{Results from the Students' Session Objectives Self-assessment Checklists}

Table 1

As a result of learning in this session, I

am aware about the essentials of Module 2

of the ELT Methodology course:

- structure and content

- outcomes

- tasks for guided observation practice

- assessment requirements.

am aware of the objectives and content of the CLT unit.

understand basic language learning and teaching notions:

- 'mother tongue'

- 'ESL'

- 'EFL'

- 'applied linguistics'

- 'language teaching methodology',

- 'approach'

- 'method'

- 'design'

- 'technique'.

can identify language teaching approaches and methods by their main features:

\begin{tabular}{|c|c|c|c|}
\hline - Audio-Lingual Method & $27(90 \%)$ & $3(10 \%)$ & \\
\hline - Audio-Visual Method & $27(90 \%)$ & $3(10 \%)$ & \\
\hline - Co mmunicative language teaching (CLT) & $27((90 \%)$ & $3(10 \%)$ & \\
\hline - Co mmunity Language Learning (counselling learning) & $18(60 \%)$ & $12(40 \%)$ & \\
\hline - Content and Language Integrated Learning (CLIL) & $14(46,7 \%)$ & $16(53,3 \%)$ & \\
\hline - Direct method & $19(63,4 \%)$ & $10(33,3 \%)$ & $1(3,3 \%)$ \\
\hline $\begin{array}{l}\text { - Grammar-Translation method } \\
\text { - Silent Way }\end{array}$ & $\begin{array}{l}22(73,3 \%) \\
24(80 \%)\end{array}$ & $\begin{array}{l}8(26,7 \%) \\
4(13,3 \%)\end{array}$ & $2(6,7 \%)$ \\
\hline - Suggestopedia & $21(70 \%)$ & $7(23,3 \%)$ & $2(6,7 \%)$ \\
\hline - Task-based learning (TBL) & $23(76,7 \%)$ & $7(23,3 \%)$ & \\
\hline - Total Physical Response (TPR). & $19(63,3 \%)$ & $9(30 \%)$ & $2(6,7 \%)$ \\
\hline
\end{tabular}

\section{5, p. 6).}

The observation of the students' engagement in the suggested activities during the two parts of the session carried out by the course teacher as well as the analysis of the students' answers given in the Session Objectives Self-assessment Checklists shortly after the session show that all the four session objectives have been reached.

In particular, the quantitative data collected from the pre-service teachers' feedback in the Session Objectives Selfassessment Checklist have demonstrated the following:

Objective 1: on average $70 \%$ of the students are fully aware about the essentials of Module 2 of the ELT Methodology course, while 23,3\% of them - to some extent;

Objective 2: $66,7 \%$ of the students are fully aware about the objectives and content of the CLT unit, while $30 \%$ of them - to some extent;

Objective 3: on average $85,2 \%$ of the students clearly understand the basic language learning and teaching notions, while $11,5 \%$ - to some extent;

Objective 4: on average $73 \%$ of the students can identify language teaching approaches and methods by their main features, while $21,1 \%$ of them - to some extent (for more detail ref. to Table 1 below).

The students' self-assessment is supported by the course teacher's observation of the completion of Objectives 1, 2, 3 and 4, which shows strong correlation, as follows:

Objective 1: $63 \%$ of the students are fully aware about the essentials of Module 2 of the ELT Methodology course, while $37 \%$ of them - to some extent;

Objective 2: $62 \%$ of the students are fully aware about the objectives and content of the CLT unit, while $38 \%$ of them - to some extent;

Objective 3: $78 \%$ of the students clearly understand the basic language learning and teaching notions, while $22 \%$ - to some extent;

Objective 4: $65 \%$ of the students can identify language teaching approaches and methods by their main features, while $35 \%$ of them - to some extent.

In our opinion, the higher scores obtained from the students' selfassessment demonstrate the typical tendency of some students to overestimating their own skills and abilities (the so called Dunning-Kruger Effect), which is replicated in the study by Krista D. Mattern, Jeremy Burrus and Emily Shaw (Krista, Burrus \& Shaw, 2010).

The qualitative data collected from 
the pre-service teachers' feedback in the open-answer Survey completed shortly after the session have also demonstrated the effectiveness of the changes introduced to the content of the CLT course, as stated in the students' answers (some quotes follow below):

Question 1: 'What new have you learned from the two parts of the session?'

"The ELT Methodology course structure and outcomes; the objectives and content of CLT unit; basic language teaching concepts, methods and approaches"; "I've discovered many language teaching methods and their main features"; "I've learned about the difference between method, approach, design and technique and their role in language teaching and learning."

Question 2: 'How might this help you as learners of Module 2 of the ELT Methodology course?'

"I think it is very important for us to know what we are to do during this semester in order to plan our learning and make it successful"; "This will help me to know how to effectively apply these methods and techniques [to] learning the language"; "Help to identify features of different approaches and methods; choose appropriate strategies and select activities; reflect on learning in the module."

Question 3: 'How might this help you as future teachers?'

"It will help me become confident and teach children correctly and effectively"; "This will help me to compare, refine and apply them in my work according to the level of students"; "I will make up my own method, using the features of the methods I learned about."

Question 4: 'Which questions are still left unanswered?'

"Theories of language and learning"; "I need to know more about how to use these methods in the classroom as a teacher"; "How to combine activities used by different methods"; "I don't know which method is the most effective."

Conclusions. The delivery of the two parts of the newly introduced session, the course teacher observation as well as the feedback from the students enable the following conclusions:

Familiarization of the students with the structure, content, and assessment specifications of Module 2, as well as with the requirements to the Guided Observation Practice created an opportunity for their successful learning on the course in Semester 4.

Understanding the main principles of language learning and teaching will help the pre-service teachers to analyse the practical value of language teaching methods and approaches they were going to learn about in the subsequent sessions of the CLT course unit - the idea also expressed by D. Larsen-Freeman (Diane LarsenFreeman on Techniques \& Principles in Language Teaching, 2020).

The completed activities enhanced the students' understanding of the main language learning and teaching concepts they need for further successful learning on the ELT Methodology course.

The suggested interaction patterns helped the students to create shared knowledge based on experience and input, as well as to develop communication skills and learner autonomy. This conclusion is supported by the idea of Vita Bosa that "dialogization of educational interaction in the process of studying major subjects contributes to the realization of the set objectives" (Bosa, 2018, p. 8).

The methods and techniques used by the course teacher (e.g. eliciting, brainstorming, reflecting, etc.) supposedly contributed to the developing of students' higher order critical thinking skills, which make the bulk of the intellectual component of the pre-service teacher's research skills, as Dariia Binetska states (Binetska, 2016, p. 6).

The learning on this introductory session raised the students' awareness of how knowledge of the history of methods can contribute to their future classroom teaching, in particular enable them to "identify distinguishing features in the pedagogical objects, phenomena and processes under study, taking into account the goals and objectives of the foreign language learning...", the idea expressed by Dariia Binetska (Binetska, 2016, p. 6).

The students still need more content knowledge and hands-on experience to be able to implement successfully in their future classrooms the teaching elements of the communicative language teaching methods and approaches they explored in the session, which actually they are going to gain in the next sessions of the CLT unit.

The student teachers need to be willing to take on responsibility for their learning of the new concepts, both in the classroom and outside of the classroom - the pre-requisite of successful autonomous language learning in general (Lamb, 2017). They should be aware of the cognitive and metacognitive learning strategies that are helpful in internalizing the new content knowledge.

To cater for this need, the course teacher should organize studentcentred learning that is engaging, motivating, and personalized. It is recommended that in the sessions the course teacher should use the methods of active and problem learning (discussions, storytelling, questioning based on Bloom's Taxonomy, examples of best teaching practices, analyses of classroom situations and authentic videos [of English lessons], etc.) that create opportunities for developing students' cognitive and creative skills, learner autonomy, engagement in research activity, which in their turn, according to Mariia Necheporenko (Necheporenko, 2019, pp. 9-10), enable student-teacher's motivation for professional and personal selfdevelopment.

For the course-teacher to use the above-mentioned methods effectively, he/she should also be able "to implement the pedagogical technology, which consists in appropriate applying technical teaching aids and organizing educational process", as stated by Marianna Bedevelska (Bedevelska, 2015, p. 8).

Prospects for further research. We consider it important to examine the other units of the Core Curriculum of the ELT Methodology course in terms of content sufficiency and to offer necessary changes; to evaluate effectiveness of the existing system of methodological training of pre-service foreign language teachers at Vasyl Stefanyk Precerpathian National University; to design a standard for professional training of pre-service foreign language teachers in Ukraine.

Appendices

Unit 2.1 Principles of Communicative Language Teaching

Part 1 Session Topic: Introduction to

Module 2 of the ELT Methodology Course

Handout 1: Expectations

Express your expectations of Module 2 of the Methodology course and share them 
with a partner

What do you expect most from your Methodology course this semester? What challenges do you anticipate?

What will you learn and what skills will you develop by successfully completing the module?

How important do you consider 'Preparing to teach 1' Module for a language teacher?

What do you expect most from your Methodology course this semester?

What challenges do you anticipate?

What will you learn and what skills will

you develop by successfully completing the module?

How important do you consider

'Preparing to teach 1' Module for a language teacher?

Unit 2.1 Principles of Communicative Language Teaching

Part 1 Session Topic: Introduction to Module 2 of the ELT Methodology Course

Handout 2: Module 2 Outcomes

Match the course units (1-4) with their outcomes (A-E). Multiple matches are possible. Share the answers with a partner.

Course Units:

1. Principles of Communicative Language Teaching

2. Teaching Grammar in Context

3. Teaching Vocabulary in Context

4. Classroom Management

Outcomes:

A Analyse classroom events with attention to organisation, modes of interaction, classroom language, classroom resources

$B$ Reflect on their learning on the module

C Identify features of different approaches and methods in classroom materials and procedures

$D$ Use classroom language appropriate to age and learning needs

E Choose appropriate strategies and select activities for teaching grammar and vocabulary in context.

Unit 2.1 Principles of Communicative Language Teaching

Part 2 Session Topic: Introduction to CLT and the History of Method

Handout 1: Basic Language Teaching Notions

Read the paragraphs below to ensure your understanding of the notions 'mother tongue,' 'ESL,' 'EFL' and 'applied linguistics.'

In learning languages, a distinction is usually made between mother tongues, second languages, and foreign languages.

A mother tongue is the first language or languages one learns (or acquires) as a child. When immigrants come to a new country and learn the language of that country, they are learning a second language. On the other hand, when Englishspeaking students in the United States learn French or Spanish in school, or when Brazilians study English in Brazil, they are learning a foreign language. The acronyms ESL and EFL stand for the learning of English as a Second and as a Foreign Language.

Many theories about the learning and teaching of languages have been proposed. These theories, normally influenced by developments in the fields of linguistics and psychology, have inspired many approaches to the teaching of second and foreign languages. The study of these theories and

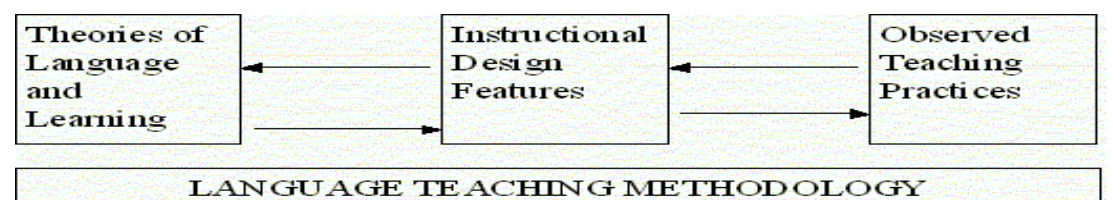

Figure 1. Lang uage Teaching Methodology

Schools of Language Teaching Methodology

how they influence language teaching methodology today is called applied linguistics. (Borrowed from www. academia.ed u/15268919/ Language_Teaching_Approaches_Review)

Unit 2.1 Principles of Communicative Language Teaching

Part 2 Session Topic: Introduction to CLT and the History of Method

Handout 2: Preliminary Reading

Read the two texts below to develop your understanding of the notions 'language teaching methodology', 'approach,' 'method,' 'design,' 'technique' and to raise awareness about a variety of approaches to and methods of language teaching and learning.

Text 1. An extract from the article 'Language Teaching Methodology' by Theodore S. Rodgers

Background

Language teaching came into its own as a profession in the last century. Central to this phenomenon was the emergence of the concept of "methods" of language teaching. The method concept in language teaching - the notion of a systematic set of teaching practices based on a particular theory of language and language learning is a powerful one, and the quest for better methods was a preoccupation of teachers and applied linguists throughout the 20th century.

Language Teaching Methodology Defined

Methodology in language teaching has been characterized in a variety of ways. A more or less classical formulation suggests that methodology is that which links theory and practice. Theory statements would include theories of what language is and how language is learned or, more specifically, theories of second language acquisition (SLA). Such theories are linked to various design features of language instruction. These design features might include stated objectives, syllabus specifications, types of activities, roles of teachers, learners, materials, and so forth. Design features in turn are linked to actual teaching and learning practices as observed in the environments where language teaching and learning take place. This whole complex of elements defines language teaching methodology. made between methods and approaches, in which methods are held to befixed teaching systems with prescribed techniques and practices, whereas approaches represent language teaching philosophies that can be interpreted and applied in a variety of different ways in the classroom. This distinction is probably most usefully seen as defining a continuum of entities ranging from highly prescribed methods to loosely described approaches.

The period from the $1950 \mathrm{~s}$ to the $1980 \mathrm{~s}$ has often been referred to as "The Age of Methods, "during which a number of quite detailed prescriptions for language teaching were proposed. Situational Language Teaching evolved in the United Kingdom while a parallel method, Audio-Lingualism, emerged in the United States. In the middlemethods period, a variety of methods were proclaimed as successors to the then prevailing Situational Language Teaching and Audio-Lingual methods. These alternatives were promoted under such titles as Silent Way, Suggestopedia, Community Language Learning, and Total Physical Response. In the 1980s, these methods in turn came to be overshadowed by more interactive views of language teaching, which collectively came to be known as Communicative Language Teaching (CLT).

Communicative Language Teaching has spawned a number of off-shoots that share the same basic set of principles, but 


\begin{tabular}{|ll} 
Audio-Lingual Method & $\begin{array}{l}\text { A method focussed on drilling key language structures orally. It is derived from the } \\
\text { behaviourist belief that repetition helps to form habits. } \\
\text { A method based on transmitting meanings through visual images and then providing } \\
\text { the language needed to communicate these meanings. }\end{array}$ \\
$\begin{array}{l}\text { Communicative language } \\
\text { teaching (CLT) }\end{array}$ & $\begin{array}{l}\text { An approach to foreign language teaching and leaming which emphasises that the } \\
\text { goal of language learning is communicative competence. The focus is on meaningful } \\
\text { communication, not structure, and on use, not usage. In this approach, learning } \\
\text { involves interaction and group work in the classroom. }\end{array}$ \\
Community Language & $\begin{array}{l}\text { A foreign language teaching method according to which learners form a 'community' } \\
\text { sitting round a tape-recorder while the teacher (counselor) remains outside the } \\
\text { community and, when necessary, supplies target-language equivalents of utterances } \\
\text { produced bylearners in their mother tongue. The recordings are transcribed and } \\
\text { presented to the learners for analysis. }\end{array}$
\end{tabular}

Content and Language Refers to bo th learning another subject, e.g. Science, through the medium of a foreign Integrated Learning language and learning a foreign language by studying a content-based subject. (CLIL) Direct method A language teaching method that excludes the use of the mother tongue and relies on demonstration of meaning in context.

Grammar-Translation The method focuses on accuracy rather than fluency and on form rather than meaning. method The key activities are drilling, translating, memorising vocabulary and learning rules.

\begin{tabular}{ll} 
Silent Way & $\begin{array}{l}\text { A method in which the teacher remains mostly silent to encourage learner autonomy } \\
\text { and active student participation. Language learning is usually seen as a problem } \\
\text { solving activity to be engaged in by the students both independently and as a group. }\end{array}$ \\
\hline Suggestopedia & $\begin{array}{l}\text { A teaching method based on the understanding of how the human brain works and how } \\
\text { we can learn most effectively in a rich sensory learning environment. }\end{array}$ \\
\hline Task-based learning & An approach to learning in which the learners use language to fulfil a specified task. \\
$(T B L)$ & Their focus is on the task rather than on the language they are using.
\end{tabular}

Total Physical Response (TPR)

A way of teaching language that coordinates speech and action, i.e. learners respond physically to teacher instructions or stories told by the teacher. It is often used in teaching young learners.

which spell out philosophical details or envision instructional practices in somewhat diverse ways. These CLT spin-off approaches include The Natural Approach, Cooperative Language Learning, ContentBased Teaching, and Task-Based Teaching.

Text 2. An extract from the book Communicative Approach to the Teaching of English as a Second Language by Pratima Dave Shastri

Before dealing with different methods and approaches in detail, let us deal with the concepts of approach, design, method and technique* in the process of language teaching and learning. Edward Anthony an American linguist developed them in 1963.

APPROACH: Refers to the philosophy of the nature of language teaching and learning. It covers linguistics and psychology. This defines 'what' and 'how' of language teaching and learning. Approach leads to method.

METHOD: Deals with an overall plan for the presentation of language material based on an approach. It is procedural. In one approach, there can be many methods. In a method, a theory is put into practice. Here, choices are made about a particular skill to be taught. It deals with content and the order of presentation. It selects grades and presents the material. Between an approach and a method there is design.

DESIGN: Gives details of a method. Here, the objectives of teaching and testing, syllabus and contents are decided. It also defines the roles of the teacher and the learner.

TECHNIQUE: Is a tool to implement the method in a classroom. Drills, role-play, group work, pair work are the techniques adopted for teaching.
We can say that 'Audio-lingual Method' is based on Oral Structural Approach. Its syllabus has the design of structural patterns and it follows the techniques of dialogue and drills in the classroom.

*See also Glossary in the Methodology course Curriculum

Unit 2.1 Principles of Communicative Language Teaching

Part 2 Session Topic: Introduction to CLT and the History of Method

Handout 3: Insight into Main Language Teaching Approaches and Methods (Cutups)

Unit 2.1 Principles of Communicative Language Teaching

Part 2 Session Topic: Introduction to CLT and the History of Method

Handout 4: The Session Objectives Selfassessment Checklist 


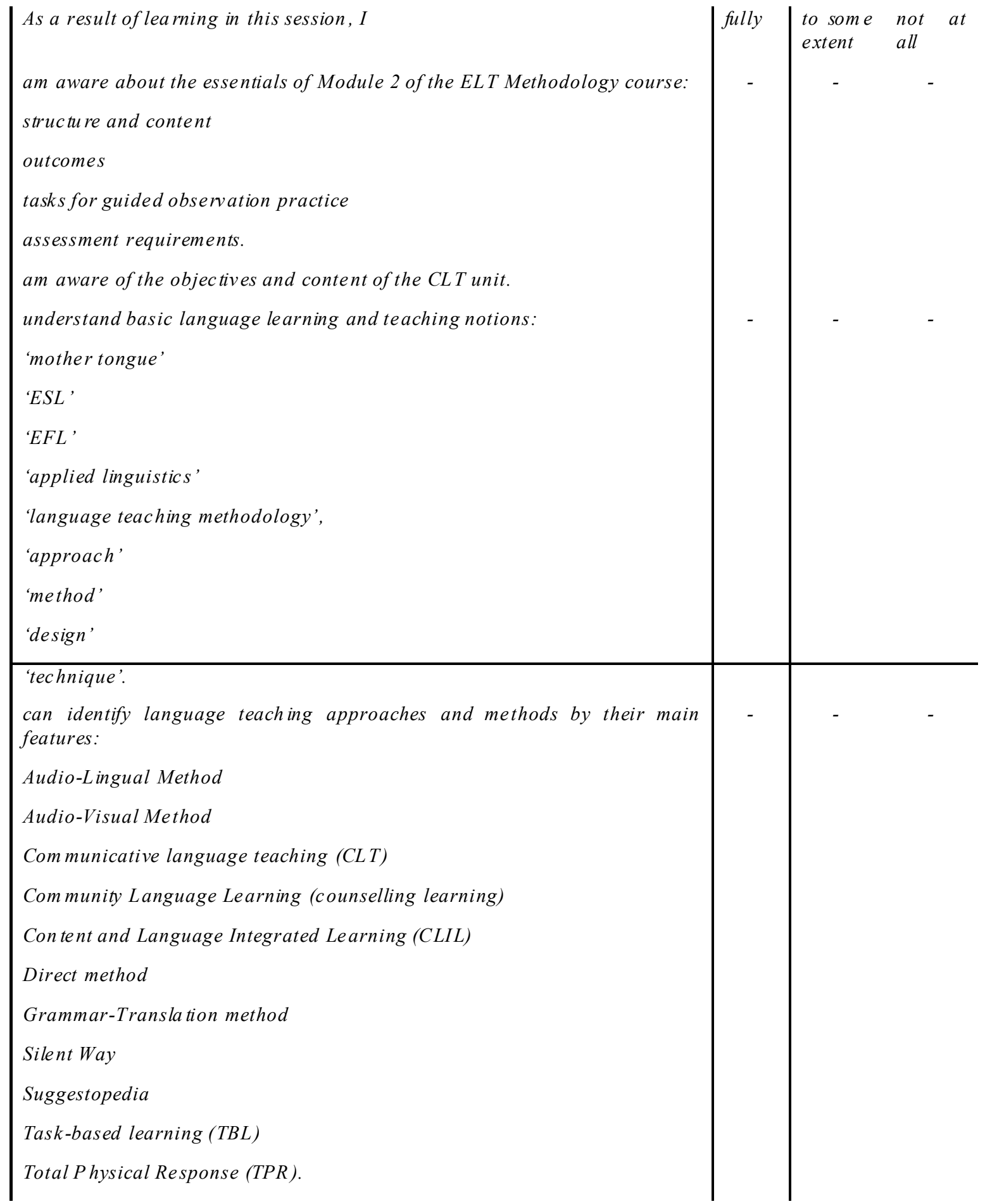

\section{REFERENCES}

Bedevelska, M. V. (2015). Formuvannya pedahohichnoyi maysternosti maybutnikh uchyteliv inozemnoyi movy na zasadakh kompetentnisnoho pidkhodu (The Formation of Future Foreign Language Teachers' Pedagogical Mastership on the Basis of Competency Approach). Khmelnytskyy: Natsionalna akademiya Derzhavnoyi prykordonnoyi sluzhby Ukrayiny imeni Bohdana
Khmelnytskoho(in Ukrainian).

Binetska, D. I. (2016). Orhanizatsiyno-pedahohichni umovy formuvannya u maybutnikh uchyteliv inozemnykh mov doslidnytskykh umin zasobamy osvitnoho seredovyshcha universytetu (Organizational and Pedagogical Conditons of Forming Future Foreign Language Teachers' Research Skills by Means of University Educational Environment). Avtoreferat dysertatsiyi na zdobuttya naukovoho stupenya kandydata pedahohichnykh nauk za spetsialnistyu 13.00.04 - teoriya ta metodyka profesiynoyi osvity. Kyiv: Natsionalnyy pedahohichnyy universytet imeni M.P. Drahomanova (in Ukrainian).

Bosa, V. P. (2018). Formuvannya movlennyevoyi kompetentnosti maybutnikh uchyteliv inozemnykh mov $\mathrm{u}$ protsesi vyvchennya fakhovykh dystsyplin (The Formation of Speech Competency of Future Teachers of Foreign Languages in the Process of Studying Professional Didciplines). 
Avtoreferat dysertatsiyi na zdobuttya naukovoho stupenya kandydata pedahohichnykh nauk za spetsialnistyu 13.00 .04 - teoriya ta metodyka profesiynoyi osvity. Zhytomyr: Zhytomyrskyy derzhavnyy universytet imeni Ivana Franka (in Ukrainian).

Diane Larsen-Freeman on Techniques \& Principles in Language Teaching (3rd ed.) [video]. Retrieved from https://www.youtube.com/ watch? $\mathrm{v}=\mathrm{cNSmrbk} Y \mathrm{Kx} 8$ [accessed 28 January 2020] (in English).

Krista, D.M., Burrus, J. \& Shaw, E. (2010). When Both the Skilled and Unskilled Are Unaware: Consequences for Academic Performance. In: Selfand Identity, Volume 9, Issue 2, 129-141 (in English).

Lamb, T.E. (2017). Knowledge about language and learner autonomy. In: Cenoz, J., \& Gorter, D. (Eds.) Language Awareness and Multilingualism. In: Encyclopedia of Language and Education. Cham, Switzerland: Springer international Publishing Switzerland, 173-186. DOI: 10.1007/978-3-319-022406 14 Retrieved from https:// www.researchgate.net/publication/ 318019412 Knonkede Abut Langugeand Lanr Atromy [accessed 20 March 2020] (in Eñ̄lish).

Language Teaching Approaches: Review. Retrieved from http:// www.academia.edu/15268919/ Language_Teaching_Approaches_Review [accessed 28 January 2020] (in English).

Leleko, V.V. (2015). Pedahohichni umovy realizatsiyi innovatsiynykh tekhnolohiy u profesiyniy pidhotovtsi maybutnikh uchyteliv inozemnoyi movy (Pedagogical Conditions of Realization of Innovative Technologies in Future Foreign Language Teachers
Professional Training). Avtoreferat dysertatsiyi na zdobuttya naukovoho stupenya kandydata pedahohichnykh nauk za spetsialnistyu 13.00.04 - teoriya ta metodyka profesiynoyi osvity. Cherkasy: Cherkaskyy natsionalnyy universytet imeni Bohdana Khmelnytskoho (in Ukrainian).

Lewis, M. \& Hill, J. (1992). Practical Techniques for Language Teaching. Fourth ed. Hove, England: Language Teaching Publications (in English).

Necheporenko, M.A. (2019). Formuvannya hotovnosti maybutnikh uchyteliv inozemnykh mov do profesi yn o-os obys tis noho samorozvytku (The Formation of Future Foreign Language Teachers' Readiness for Professional and Personal Development). Avtoreferat dysertatsiyi na zdobuttya naukovoho stupenya kandydata pedahohichnykh nauk za spetsialnistyu 13.00 .04 - teoriya ta metodyka profesiynoyi osvity. Ternopil: Ternopilskyy natsionalnyy pedahohichnyy universytet imeni Volodymyra Hnatyuka (in Ukrainian).

Rodgers, Th.S. (2001). Language Teaching Methodology (ERIC Issue Paper). Washington, DC: ERIC Clearinghouse on Languages and Linguistics. Available as Ten New Scenarios for Language Teaching Methodology. Retrieved from http:// www. shareeducation.com.ar/ pastissues3/187.htm [accessed 27 January 2020] (in English).

School Experience Observation Tasks Module 2. In: Core Curriculum. English Language Teaching Methodology. Bachelor's Level. Retrieved from https:// $1 \mathrm{fd} 10 \mathrm{c} 7 \mathrm{a}-6813$ 41b3-98e8-e5598ca6cc9b.filesusr.com/ ugd/15b470_0e8f46c8216a4a55b0 d558683e0c0941.pdf [accessed 26 January 2020] (in English).

Shastri, P.D. (2010). Communicative Approach to the Teaching of English as a Second Language. Mumbai, Delhi, Nagpur, Bangalore, Hyderabad: Himalaya Publishing House, 33-41 (in English).

Supplementary Materials Module 1. In: Core Curriculum. English Language Teaching Methodology. Bachelor's Level. Retrieved from https://1fd10c7a$\begin{array}{lllllllllllll}6 & 8 & 1 & 3 & - & 4 & 1 & \text { b } & 3 & -9 & 8 & \text { e } & 8\end{array}-$ e5598ca6cc9b.filesusr.com/ugd/ 15b470_49543134e4

9345ab9651a0ea320ae097.pdf [accessed 26 January 2020] (in English).

Supplementary Materials Module 2. In: Core Curriculum. English Language Teaching Methodology. Bachelor's Level. Available Retrieved from https:/ / 1 fd 10 c 7 a - $6813-41$ b3 -98 e 8 e5598ca6cc9b.filesusr.com/ugd/ 15b470_8952329a4bd945d

$1 \mathrm{~b} 58 \mathrm{~d} 528609 \mathrm{f} 4 \mathrm{e} 0 \mathrm{e} 9 . p d f$ [accessed 26 January 2020] (in English).

Typova prohrama "Metodyka navchannya anhliyskoyi movy". Osvitniy stupin bakalavra. (2020). (Core Curriculum. English Language Teaching Methodology. Bachelor's Level). Ivano-Frankivsk: NAIR. Available Retrieved from https:// ngschoolteacher.wixsite.com/ngscht/ core-curriculum-1 [accessed 26 January 2020] (in Ukrainian and English).

What are the 21 st-century skills every student needs? Retrieved from https://www.weforum.org/agenda/ 2016/03/21st-century-skills-futurejobs-students/ [accessed 28 January 2020] (in English).

Стаття надійшла 27.03.2020р. 